\title{
Arktisk opvarmning og dansk sikkerhedspolitik
}

\section{Nikolaj Petersen}

\begin{abstract}
Den globale opvarmning kræver såvel teknologiske og økonomiske tilpasninger som politiske - herunder sikkerhedspolitiske - tiltag for at fremme internationalt samarbejde og håndtere konflikter $\mathrm{i}$ kølvandet af klimaændringer
\end{abstract}

'Truslen' fra den globale opvarmning kan håndteres på to måder: Ved at manipulere de faktorer, der betinger opvarmningen, eller ved aktivt at tilpasse sig til dens virkninger. Den første tilgang i form af en globalt forhandlet reduktion af udledningen af $\mathrm{CO}_{2}$ og andre drivhusgasser var strategien for COP15-konferencen i København. Den kan imidlertid ikke stå alene. Selv med det gunstigste udfald af konferencen eller efterfølgende forhandlinger vil opvarmningen fortsætte en rum tid, og her kommer tilpasningsstrategierne ind som et nødvendigt supplement med det dobbelte sigte at afbøde opvarmningens negative virkninger og udnytte dens positive effekter. Ud over teknologiske og økonomiske tilpasninger vil der bli- ve behov for politiske, inklusive sikkerhedspolitiske tiltag til fremme af nødvendigt internationalt samarbejde samt til håndtering af konflikter i kølvandet af klimaændringerne.

Denne artikel vil koncentrere sig om klimaændringernes implikationer for dansk sikkerhedspolitik, som er evidente i to sammenhænge: Den globale ordensproblematik, som Danmark har været dybt involveret i siden den kolde krigs afslutning, og den nytilkomne problemstilling omkring Arktis som en selvstændig sikkerhedspolitisk region, hvor Danmark via Grønland har en række nationale interesser at varetage. (For en bred analyse af de udenrigspolitiske implikationer af den arktiske opvarmning, se min artikel 'The Arctic as a New Arena for Danish 
Foreign Policy: The Ilulissat Initiative and its Implications' i Danish Foreign Policy Yearbook 2009, s. 35-78.) Gennem Forsvarskommissionen af 2008 og det nye forsvarsforlig fra juni 2009 er Arktis bragt ind på den hjemlige sikkerhedspolitiske dagsorden som en selvstændig, men fortsat underordnet problematik ved siden af den globale ordenspolitik.

\section{Udfordringer for forsvaret}

Som aktiv deltager i bestræbelserne for at bygge en ny liberal verdensorden deler Danmark den overordnede vestlige trusselsvurdering af den internationale terrorisme, udbredelsen af masseødelæggelsesvåben samt forekomsten af skrøbelige eller sammenbrudte stater (failed states) som hovedtruslerne. Klimaændringerne vil med stor sandsynlighed skærpe problemerne omkring failed states ved at skabe øget konkurrence om knappe ressourcer som vand og land med deraf følgende social uro, politiske sammenbrud, migrationsstrømme og terrorisme.

Forsvarskommissionen af 2008 udpeger Afrika som det kontinent, der vil være mest udsat for klimaændringer og ringest rustet til at imødegå dem. Den forventer derfor, at Danmark frem mod 2025 vil skulle bidrage militært til operationer i Afri$\mathrm{ka}$, herunder indsatser i forbindelse med naturkatastrofer. Dermed er den globale opvarmning formentligt en af præmisserne for kommissio- nens 'optimistiske' forventning om en uformindsket efterspørgsel efter danske militære indsatser ude i verden i fremtiden.

Denne analyse følges op i forsvarsforliget af juni 2009, der noterer, at danske styrker fortsat skal kunne udkæmpe konventionelle konflikter uden for Europa, men at der samtidig vil være stigende behov for at kunne sætte ind med andre typer aktioner så som oprørsbekæmpelse, fredsskabende indsatser eller hjælp til genopbygning.

Forligspartierne slutter sig derfor til anbefalingen fra Kommissionen om at fastholde forsvarets evne til at deltage i internationale operationer. Men samtidig peger forligspartierne på de nye udfordringer for forsvaret som følger af Arktis' voksende geostrategiske betydning. Hverken Kommissionen eller forligspartierne rejser dog spørgsmålet om den prioritering af de to opgavetyper, som kan blive aktuel i et længere perspektiv.

\section{Klimaændringer i Arktis}

På kort og mellemlangt sigt vil Arktis være blandt de regioner i verden, der påvirkes kraftigst af den globale opvarmning. Siden et videnskabeligt panel under Det Arktiske Råd i 2004 konkluderede, at Arktis var under hurtig opvarmning, og at endnu større klimaændringer kunne ventes i fremtiden, har der dannet sig en videnskabelig konsensus om, at opvarmningen af Arktis er omtrent 
dobbelt så stor som i andre regioner, og at den går hurtigere, end de gængse klimamodeller forudsiger.

Nogle forskere imødeser muligheden af snarlige 'tipping-points', hvor opvarmningen accelererer med uforudsigelige konsekvenser som følge.

I modsætning til mange andre regioner vil opvarmningen i Arktis foruden en række negative konsekvenser også have betydelige, gunstige virkninger. I Grønland vil den virke negativt ind på det højarktiske økosystem og undergrave grundlaget for fangerkulturen, men have gunstig indvirkning på mulighederne for den økonomiske vækst og modernisering, som der er dansk-grønlandsk enighed om at tilstræbe. Temperaturstigninger på op imod 8 grader vil begunstige erhverv som landbrug og gartneri såvel som minedrift og evt. tung industri.

Det er imidlertid offshore, at det mest interessante økonomiske vækstpotentiale ligger. Den afgørende faktor er her afsmeltningen af isen i Det Arktiske Ocean og dens virkning på skibsfart, olie- og gasudvinding og fiskeri i regionen.

Det Arktiske Ocean har været isdækket siden sidste mellemistid for over 100.000 år siden, men siden satellitmålinger begyndte i 1978 har der kunnet konstateres en betydelig sommerafsmeltning, der har skabt forventninger om et isfrit ocean i dette århundrede. Det foreløbige minimum blev nået i september
2007 med et isdække på 4,24 mio. $\mathrm{km}^{2} \bmod$ ca. 8 mio. $\mathrm{km}^{2}$ i 1980 'erne. Samtidig er isens gennemsnitstykkelse omtrent halveret. Afsmeltningen er særlig stor i oceanets sydlige dele, inkl. Nordøst- og Nordvest-passagerne mellem Atlanterhavet og Stillehavet, der begge har været passable for sommersejlads de seneste år. Såfremt afsmeltningen fortsætter, åbner der sig gode muligheder for besparelser på varetransporten mellem Vesteuropa og Østasien.

Et andet perspektiv er muligheden for, at offshore-udvinding af olie og gas kan tage fart. De seneste år er der fremkommet nye estimater af Arktis' kulbrintereserver, først og fremmest fra det amerikanske US Geological Survey. USGS kom i 2008 med et middelestimat for hele Arktis på $412 \mathrm{BBOE}$ (Billion Barrels of Oil Equivalents), hvoraf olieforekomster tegnede sig for $90 \mathrm{BBOE}$, svarende til 13 procent af verdens 'uopdagede' oliereserver.

Hovedparten findes ud for Sibirien og Alaska, men USGS regner også med betydelige forekomster ud for Nordøstgrønland (31 BBOE), hvilket vil kunne gøre området til nr. 19 blandt verdens kendte olieprovinser. Også den øst-canadisk-vestgrønlandske region tilskrives betydelige reserver, i alt $17 \mathrm{BBOE}$. Arktis er således en lovende kulbrinteregion, men forudsætningen for en fuld kommerciel produktion er en yderligere afsmeltning af havisen.

Endelig åbner opvarmningen af 
Arktis for et forbedret og mere nordligt fiskeri i Arktis. Med stigende havtemperaturer er der fx udsigt til, at torsken vender tilbage til grønlandske farvande, og generelt kan der konstateres en nordgående migration af fiskebestandene, som trækker fiskeriet med sig mod nord.

\section{Arktis: Konfliktpotentiale...}

De klimabetingede udsigter til øget økonomisk aktivitet i arktiske farvande skærper interessen for de territoriale afgrænsninger i regionen. Situationen er den, at alle fem kyststater omkring Det Arktiske Ocean, Danmark/Grønland, Norge, Rusland, USA og Canada, med hjemmel i UNCLOS-havretskonventionen af 1982 har oprettet såkaldt eksklusive $\varnothing$ konomiske zoner (EEZ) med eneret til al ressourceudnyttelse ud til 200 sømil fra deres kystbasislinjer,.

Derudover åbner konventionens art. 76 mulighed for, at signatarmagterne $\mathrm{i}$ indtil 10 år efter deres ratifikation kan fremsætte dokumenterede krav på de dele af kontinentalsoklen, som strækker sig indtil 150 sømil uden for deres EEZ, hvor de mod en afgift til FN's International Seabed Authority kan udnytte havbundens ressourcer.

I Det Arktiske Ocean er interessen især knyttet til den såkaldte Lomonosov Ryg, som både Rusland og Canada/Danmark anser for en naturlig forlængelse af deres kontinentalsokler. Danmark søger i det så- kaldte Kontinentalsokkelprojekt at stille en videnskabelig dokumentation på benene for sine krav på en udvidet grønlandsk kontinentalsokkel i retning Nordpolen.

Konflikter om territorium og suverænitet hører til de vanskeligste at løse, jf. den årelange dansk-canadiske strid om den betydningsløse Hans $\varnothing$ i Nares-strædet. Norge og Danmark har aftalt at løse eventuelle overlappende krav på den ydre kontinentalsokkel ad forhandlingsvejen, men det er ikke givet, at alle interessenter vil være indstillet på det samme, eller at sådanne forhandlinger fører til en løsning.

Norge og Sovjetunionen/Rusland har således i mange år været uenige om grænsedragningen i Barentshavet, uden at en løsning er rykket nærmere. Andre potentielle konfliktspørgsmål relaterer sig til Nordøst- og Nordvestpassagerne, som henholdsvis Rusland og Canada betragter som interne vandveje, men som USA ud fra princippet om havenes frihed anser for internationale. Uenigheden står også om UNCLOS art. 234, der tillader kyststater at gennemtvinge ikke-diskriminatoriske miljøbestemmelser i isdækkede farvande inden for deres $ø$ konomiske zoner.

Et andet konfliktpotentiale ligger i det, som man har kaldt 'militariseringen' af Arktis, dvs. kyststaternes forøgelse af deres militære kapaciteter og aktiviteter i regionen. Særlig opmærksomhed har været rettet 
mod Canadas og Ruslands politik.

I Canada har den konservative premierminister Stephen Harper siden 2006 ført en aktivistisk arktisk politik under devisen 'use it (suveræniteten) or lose it' og med proklamationer af, at 'Canada has real, growing long-term presense in the Arctic'. På denne deklaratoriske baggrund er der udarbejdet en ganske ambitiøs plan for militær tilstedeværelse i canadisk Arktis omfattende både flåde- og hærenheder. De foretagne investeringsbeslutninger svarer dog ikke ganske til den hårde retorik.

Retorikken omfatter blandt andet udenrigsminister Lawrence Collins' udtalelse om, at Canada ikke vil lade sig 'be bullied' af Rusland i forsvaret af sin suverænitet. Dette var et svar på en øget russisk patruljevirksomhed i Arktis siden 2007, inkl. påståede krænkelser af canadisk luftrum.

Ruslands Arktis-politik har skabt usikkerhed blandt de øvrige kyststater ved sin blanding af en lejlighedsvis stærk retorik og forøget militær aktivitet på den ene side og beroligende formuleringer af den deklaratoriske politik på den anden.

I sommeren 2007 skabte en russisk flagplantning under Nordpolen og intensiveringen af fly- og skibspatruljer i det arktiske område uro blandt de øvrige kyststater, inklusive Danmark og Norge. På samme vis er den nylige beslutning om på sigt at oprette en særlig arktisk styrke blevet mødt med bekymring hos andre kyststater. På den anden side peger Ruslands tiltræden af Ilulissat-erklæringen i maj 2008 (se nedenfor) og udtalelser om, at Rusland vil respektere UNCLOS-proceduren vedr. delingen af den arktiske kontinentalsokkel i retning af, at Rusland der i forvejen står som vinderen af det arktiske 'lotteri'- ser sin interesse i et samarbejde med andre arktiske kyststater. Ruslands hovedinteresse er den effektive udnyttelse af ressourcerne i Arktis, der ifølge præsident Medvedev i fremtiden vil stå for over 20 pct. af Ruslands BNP og eksportindtægter, og denne udnyttelse kan ikke blive optimal i et spændt sikkerhedspolitisk klima.

USA har hidtil ført en lav profil i Arktis, hvad der delvis hører sammen med, at det endnu ikke har underskrevet UNCLOS-konventionen. Det er dog formentlig kun et spørgsmål om tid, før det sker, idet ikkedeltagelsen i UNCLOS ikke giver USA ret til at deltage i delingen af den ydre kontinentalsokkel.

Både den afgående Bush-administration og den nye Obama-administration har opgraderet Arktis' rolle i amerikansk politik, men USA's militære og civile kapacitet i regionen Arktis er begrænset, hvad der giver Rusland en regional overlegenhed.

Ud over det konfliktpotentiale, der ligger i de konkrete interessemodsætninger i Arktis og risikoen for lokale rustningskapløb, er der grund til at nævne risikoen for spillover fra konflikter i andre dele af 
verden. I sommeren 2008 var der således frygt for, at konflikten mellem Rusland og NATO om Georgien kunne brede sig til Arktis, og generelt må man regne med, at situationen i Arktis vil være afhængig af det overordnede forhold mellem NATO-landene og Rusland.

\section{... og samarbejdsmuligheder}

Over for dette konfliktpotentiale står en række muligheder for samarbejde og regimedannelse i Arktis: For det første kan en række grænseoverskridende problemer som forurening fra olie- og gasproduktion eller skibsfart mest hensigtsmæssigt håndteres ved et regionalt samarbejde. For det andet gør generel ressourceknaphed i forbindelse med et højt arktisk omkostningsniveau fælles løsninger attraktive, frem for at hver kyststat for sig søger at løse opgaverne. For det tredje må der påregnes pres fra ikke-kyststater og EU om samarbejdsløsninger, der også varetager deres interesser. Og endelig er der den fælles interesse for kyststaterne i samarbejde frem for konflikt, at fuld udnyttelse af de økonomiske muligheder næppe kan forenes med et spændt sikkerhedspolitisk miljø. Det vil fx blive vanskeligt at udnytte de forøgede sejladsmuligheder optimalt, hvis der opstår konflikt omkring sejlrettigheder eller regelsæt for den arktiske skibsfart.

De områder, hvor der umiddelbart kan identificeres et behov for samarbejde og regimedannelse, er funktioner som søopmåling, tilmeldingssystemer for skibe, der sejler ind i de arktiske farvande, skibscertificering til arktisk sejlads, search and rescue-beredskab, vejr- og istjenester og fremskaffelse af isbryderkapacitet. Ligeledes vil der kunne opstå behov for fælles regler vedrørende forurening fra olieproduktion, samarbejde om katastrofeberedskab eller bevaringssystemer for arktisk fiskeri.

Grundlaget for et sådant samarbejde, som bliver aktualiseret, efterhånden som de fysiske betingelser for de pågældende aktiviteter bliver skabt, er for så vidt allerede formuleret i den såkaldte Ilulissat-erklæring fra maj 2008, som udenrigsminister Per Stig Møller tog initiativ til.

Ideen, der blev lanceret umiddelbart efter den russiske magtdemonstration i august 2007, var at samle de fem kyststaters udenrigsministre til en konference i Ilulissat med henblik på at forpligte dem til at løse de nye udfordringer i Arktis gennem 'dialog, samarbejde og forhandling' og til at anvende UNCLOS-regelsættet i forbindelse med delingen af den ydre kontinentalsokkel.

Resultatet blev Ilulissat-erklæringen, hvor de fem kyststater tildeler sig selv et særligt ansvar for den fremtidige håndtering af spørgsmål vedrørende Det Arktiske Ocean, samtidig med at de lover at leve op til det. Erklæringen er nok ganske 
generel i sine formuleringer, men kan, hvis den følges op med specifikke initiativer, danne rammen om regimedannelser på de ovennævnte områder og med kyststaterne som primære leverandører af services.

Det er en klar dansk-grønlandsk interesse at holde parterne fast på erklæringen, hvad der synes at forudsætte, at man fra dansk side viser rettidig omhu med henblik på at fremme konkret samarbejde mellem kyststaterne; Ilulissat-erklæringen gør det ikke alene.

\section{Fremtidige opgaver}

Uanset de stærke argumenter for en fredelig, samarbejdspræget udvikling i Arktis kan man ikke overse potentialet for konflikt og uenighed. Dansk Arktis-politik må derfor indrettes på at skulle bevæge sig på et kontinuum af samarbejde og konflikt. Figur 1 illustrerer, hvilke specifikke opgaver, der vil kunne stille sig inden for dette kontinuum, opdelt på fire kategorier: 'Regimeopgaver', myndighedsopgaver, suverænitetsopgaver og egentlige forsvarsopgaver.

Regimeopgaver refererer til opgaver, som Danmark vil måtte påtage sig på Grønlands vegne inden for mulige fremtidige arktiske regimer. Der er her tale om opgaver, der ellers ville være nationale myndighedsopgaver, men som det er i dansk interesse at finde fælles løsninger på, både af økonomiske og sikkerhedspolitiske årsager. Jo stærkere regimer, der kan dannes i Arktis, des mindre bliver konfliktpotentialet, og des mindre behov vil der være for en egentlig forsvarsindsats i Grønland.

Der er således en tæt sammenhæng mellem regime- og myndighedsopgaver. I den udstrækning de pågældende opgaver ikke kan løses ved internationalt samarbejde, må de varetages nationalt. Samtidig vil der dog være nationale myndighedsopgaver, der ikke kan overdrages til fælles løsning, fx politimyndighed og størsteparten af miljø- og fiskeri-

Figur 1. Potentielle arktiske opgaver for dansk udenrigs- og sikkerhedspolitik

\begin{tabular}{|l|l|l|l|}
\hline Samarbejde & \multicolumn{2}{|c|}{ Konflikt } \\
\hline Regimeopgaver & Myndighedsopgaver & Suverænitetsopgaver & Militære opgaver \\
Søopmåling & Søopmåling & Luftovervågning & Afvisningsberedskab \\
Meldesystem & Meldesystem & Farvandsovervågning & Krisestyring \\
Search \& Rescue & Search \& Rescue & Territorieovervågning & Forsvar \\
Skibscertificering & Politimyndighed & & \\
Is/vejrtjeneste & Is/vejrtjeneste & & \\
(Miljøkontrol) & Miljøkontrol & & \\
(Fiskerikontrol) & Fiskerikontrol & & \\
\hline
\end{tabular}


kontrollen. Fælles for de eventuelle regimeopgaver og myndighedsopgaverne omkring Grønland er, at de af praktiske kapacitetsmæssige årsager traditionelt varetages af forsvaret, uanset at der er tale om 'civile' opgaver, der i en række andre lande, fx USA og Norge, varetages af en særskilt kystvagttjeneste. Hvad enten opgaveløsningen sker i fælles eller nationalt regi, vil denne type opgaver blive flere og mere tungtvejende i takt med den øgede økonomiske aktivitet i Arktis.

Det samme gælder de egentlige suverænitetsopgaver som overvågning af luft-, sø- og landterritoriet, som normalt varetages på strikt national basis. Det kan her overvejes, om der kan blive tale om et samarbejde med de andre NATO-kyststater, fortrinsvis Canada og Norge, $\mathrm{fx}$ om flyovervågningen af Det Arktiske Ocean.

For Grønlands vedkommende vil kravene til farvandsovervågningen stige med udvidelsen af søterritoriet til den ydre kontinentalsokkel, med udsigten til øget skibsfart, fx krydstogtsejlads, i farvandene omkring øen Grønland og med en forøget militær tilstedeværelse i Arktis. Dertil kommer det fortsatte behov for den territorieovervågning, som Sirius-patruljen står for.

Endelig er der de rent militære opgaver, som vil kunne få et større omfang end hidtil i form af et afvisningsberedskab over for suverænitetskrænkelser, en krisestyringskapa- citet til indsætning i regionale krisesituationer samt en egentlig forsvarskapacitet.

Disse opgaver har stort set ikke været varetaget op til nu. Det danske forsvars beskedne tilstedeværelse i Grønland har udelukkende til formål at varetage myndigheds- og suverænitetsopgaver. Uanset at forsvarsoverenskomsten med USA af 1951 formelt drejer sig om Grønlands forsvar, har realiteten været, at USA heller ikke har opstillet noget territorielt forsvar for Grønland; selv Thule-basen har ikke haft noget aktivt forsvar siden midten af 1960'erne.

Den begyndende militarisering af Arktis i Canada og Rusland kunne i sig selv være et argument for, at 'so ein Ding müssen wir auch haben', dvs. at også Danmark må følge med i opbygningen af en egentlig forsvarskapacitet i Grønland. Det er imidlertid et tveægget argument med potentielt kontraproduktive konsekvenser, nemlig hvis danske tiltag (hvor beskedne de end er) kommer til at øge 'sikkerhedsdilemmaet' og bidrage til en negativ spiral af rustninger og gensidig mistillid. Det indikerer forsigtighed og omtanke i forbindelse med militære dispositioner og en aktiv afbalancering af disse med samarbejdsinitiativer.

\section{How much is enough?}

Den danske forsvarskapacitet i Grønland blev i 1995 samlet under Grønlands Kommando, GLK, en 
værnsfælles niveau 2-myndighed, der løser sine operative opgaver ved tildelte kapaciteter fra værnene, primært Søværnet. Disse opgaver omfatter overvågning, suverænitetshævdelse og en række af de næunte myndighedsopgaver, men ikke egentlige forsvarsopgaver.

Kommandoen disponerer ud over sin hjemmebase på Marinestation Grønnedal over en del af Søndre Strømfjord, hvor Luftgruppe Vest er baseret, over Station Nord i Nordøstgrønland (med landingsbane) og endelig en landingsbane i Mestersvig. På materielsiden råder Søværnet over fire inspektionsskibe af Thetisklassen, hvoraf et er permanent tildelt Grønlands Kommando. Hertil kommer de to nytilgåede inspektionsfartøjer af Knud Rasmussen-klassen, der afløser de langt mindre inspektionskuttere af Agdlek-klassen, hvoraf der kun er én enhed tilbage.

Denne udskiftning indebærer en betydelig kapacitetsforøgelse, efter at tendensen i nogen tid havde været en vis udtynding til fordel for de internationale missioner. Hertil kommer et Challenger-overvågningsfly, der er til rådighed ca. 8 dage om måneden. Endelig hører Sirius-patruljen med basis i Daneborg ind under GLK.

Er det nok til at klare fremtidens opgaver? Og i hvor høj grad er det nødvendigt at tage højde for et militært beredskab omkring Grønland? I en nylig rapport fra DIMS, Dansk
Institut for Militære Studier, med den tvetydige titel Hold hovedet koldt! analyserer forfatterne forsvarets opgaver i Grønland frem mod år 2030 (Henrik Jedig Jørgensen \& Jon Rahbek-Clemmensen, Hold hovedet koldt! En scenariebaseret undersøgelse af forsvarets opgaver $i$ Grønland frem mod 2030, København, DIMS, maj 2009).

Det sker i form af fire scenarier for det fremtidige Grønland på grundlag af dimensionerne 'ressourcedrevet økonomisk vækst' og 'militarisering'. De fire scenarier kaldes henholdsvis 'naturskøn rasteplads' (hverken vækst eller militarisering), 'Klondyke' (vækst uden militarisering), 'militærbase' (militarisering uden vækst) og endelig 'rig, men skræmt' (både vækst og militarisering). Af disse anser forfatterne de to første for sandsynlige, mens de to militariseringsscenarier vurderes som meget usandsynlige.

Når militariseringsscenarierne anses for meget usandsynlige, hænger det sammen med forfatternes antagelse af, at en militarisering vil have sit udspring i, at Rusland følte sig truet af NATO's adfærd i Arktis eller i andre regioner. "Med udgangspunkt i Ruslands kapabiliteter og interesser er en sådan konflikt [dog] meget usandsynlig" (s. 21.), idet Rusland antages hverken at have ressourcer til eller interesse i en konflikt med NATO i det høje nord.

Ud fra en præmis om, at det er i dansk interesse at undgå en militarisering af Arktis, anbefaler rappor- 
ten, at Danmark udviser stor tilbageholdenhed og ikke unødigt forøger sin militære tilstedeværelse, således at det virker truende over for potentielt fjendtlige magter. Tværtimod bør man investere energi og ressourcer $i$ at udvikle og vedligeholde dialogfora med deltagelse af disse stater.

Analysen medgiver, at der bliver behov for en effektivisering af de nuværende kapaciteter i Grønland, først og fremmest i form af organisatoriske ændringer og en stærkere prioritering af opgaverne. Kun såfremt dette ikke er tilstrækkeligt, kan man forsøge at øge kapaciteten, men gøre det forsigtigt og henholdende, og overordnet set bør Danmark undlade at problematisere Arktis i NATO-regi for ikke at bidrage til russiske trusselsbilleder.

Tidligere udenrigsminister Uffe Ellemann-Jensen har en anden og mere kontant analyse. I en kronik i Berlingske Tidende ('Derfor skal vi have dansk militær i Grønland', 24. juli 2009) harcelerer han over, hvad han kalder "forskrækkede kommentarer om, at Danmark risikerer at provokere Rusland, hvis vi 'opruster' i Arktis".

For det første betoner den tidligere udenrigsminister konfliktpotentialet i Arktis, uanset de gensidige løfter om at overholde gældende regler, hvorfor han finder det helt legitimt at være til stede militært i området for at sikre lov og orden - eller være forberedt herpå. For det andet er Danmark i kraft af det fortsatte Rigsfællesskab forpligtet til varetage forsvaret af Selvstyre-Grønland og dets internationale interesser. $\mathrm{Og}$ for det tredje har Danmark en solidarisk forpligtelse til ikke at køre på frihjul i forhold til for de øvrige NATO-kyststater: "Vi skal også selv have tropper og skibe og fly, der kan operere i Arktis ...."

Hvor rapporten fra DIMS i sin tilgang ligger i forlængelse af den forsigtige danske småstatstradition med vægt på ikke-provokation af stormagtsnaboer, er Uffe EllemannJensen mere på linje med den aktivistiske, 'militariserede' tilgang til sikkerhedspolitikken, der har hersket efter den kolde krig, og som har forkastet småstatsrollen til fordel for mellemstatens mere 'ansvarlige' rolle.

\section{Arktisk sikkerhedspolitik 2010-14}

I juni 2009 sluttedes et bredt forsvarsforlig for årene 2010-14 mellem Folketingets partier spændende fra SF til Dansk Folkeparti. Som nævnt fortsætter forliget forsvarets internationalisering inden for en aktivistisk udenrigspolitisk ramme, således at kommende klimaændringer indgik i den brede begrundelse herfor.

Med hensyn til Arktis er forligets præmis Forsvarskommissionens forventning om, at den stigende $\varnothing \mathrm{ko}-$ nomiske aktivitet i Arktis vil give kyststaterne nye og forøgede suverænitets- og myndighedsopgaver. For- 
mentlig bygger forliget også på FE's seneste risikoanalyse, Efterretningsmessig risikovurdering 2009, der anser det for usandsynligt, at flere kyststaters igangværende styrkelse af deres militær i Arktis vil føre til militære konflikter.

På mellemlangt til langt sigt er der dog risiko for mindre sammenstød og diplomatiske kriser, hvor væsentlige strategiske og energimæssige interesser tørner sammen. "Konfrontationerne vil fx kunne bestå i militær chikane af andre staters militære styrker eller deres civile udnyttelse af naturressourcerne i de omstridte områder", er vurderingen (s. 20).

Forsvarsforliget går ikke direkte ind på spørgsmålet, om der vil være et behov for en egentlig forsvarskapacitet i Grønland, men visse bestemmelser i det kan tolkes i den retning. Hovedvægten ligger dog klart på en styrkelse af evnen til at gennemføre myndigheds- og suverænitetsopgaver. Forligets bestemmelser vedrørende Arktis omfatter såvel planlægningsmæssige, organisatoriske og materielmæssige bestemmelser.

Forligsteksten rummer to bestemmelser om en nærmere analyse af den nye arktiske problematik. For det første skal der gennemføres en egentlig risikoanalyse for havmiljøområdet, der tager højde for den forventede udvidelse af trafikmængden og aktivitetsniveauet i forligsperioden. For det andet og vigtigere iværksættes en omfattende analyse af forsvarets opgaver i Arktis, inklusive fordelene ved et tættere samarbejde med andre nordiske lande, USA, Canada, Rusland og UK om overvågning og lignende.

Undersøgelsen skal specifikt overveje mulighederne for at anvende kampfly til overvågning og suverænitetshævdelse ved Grønland samt for at styrke inspektionsflykapaciteten på kort sigt, dvs. inden for forligsperioden. Der tænkes her formentlig på anvendelse af propelfly af Twin Otter-typen.

Organisatorisk er der tale om tre 'nyheder' i forliget. For det første et forslag om at oprette en værnsfælles arktisk kommando ved at slå GLK og den tilsvarende Færøernes Kommando sammen - formentlig med placering i Nuuk. For det andet skal der ud fra forsvarets eksisterende kapaciteter udpeges en arktisk indsatsstyrke, der situationsbestemt kan etableres og sammensættes af enheder af alle værn med en arktisk kapacitet. "Indsatsstyrken vil medvirke til en generelt større dansk kompetence på området og vil kunne indsættes i Grønland eller i internationale opgaver i arktisk miljø”. Det tredje initiativ er en undersøgelse af mulighederne for at inddrage Thule-basen i forsvarets opgaveløsning i samarbejde med andre partnerlande.

Endelig giver anskaffelsesbeslutningerne visse fingerpeg. Disse er centreret om en forbedring af over- 
vågningen i Grønland. Forliget indebærer, at de nuværende $L y n x$-helikoptere på de større fartøjsenheder erstattes af en kraftigere og mere effektiv helikoptertype, der kan anvendes både i Arktis og internationalt. Endvidere forudsættes det, at der fra 2017 indsættes en tredje enhed af Knud Rasmussen-klassen til overvågning $\mathrm{og}$ fiskeriinspektion ved Grønland.

Forligets umiddelbare sigte er således en forbedret overvågning $\mathrm{og}$ suverænitetshævdelse i forventning om en stigende skibstrafik og anden økonomisk aktivitet i grønlandske farvande. Vedrørende andre opgaver og deres løsning er forliget mere tilbageholdende, formentlig i afventen af den bebudede omfattende analyse af den fremtidige opgaveløsning i Arktis. Denne analyse, der formentlig iværksættes efter forligets ikrafttræden pr. 1. januar 2010, vil blive et vigtigt grundlag for forsvarsordningen efter $2014 \mathrm{og}$ hermed for forsvarets rolle i Arktis på længere sigt.

\section{Arktisk kommando}

Der udlægges dog visse spor med forsvarsforliget. Det mest konkrete er forslaget om en arktisk kommando. Dette forslag er dog en udløber af en anden og ældre problematik, nemlig spørgsmålet om en rationalisering af forsvarets organisation i det nordatlantiske område, der har været under overvejelse i længere tid.

Forslaget, der karakteristik nok går på en arktisk, ikke en nordatlantisk kommando, vil indebære en mere fleksibel anvendelse af de tildelte styrker og desuden tillade en evakuering af det isolerede hovedkvarter i Grønnedal. Det er endnu uafgjort, hvor hovedkvarteret skal ligge, men alt peger på Nuuk, hvad der dels vil indebære besparelser, dels fremme et nærmere samarbejde med det grønlandske Selvstyre om opgaveløsningen. Det vil bl.a. indebære en mulighed for, at Selvstyret overtager flere af inspektionsopgaverne ved Grønland.

En anden ide er benyttelse af Thule-basen til forsvarets opgaveløsning i Grønland 'i samarbejde med andre partnerlande', hvorved givetvis tænkes på USA og måske også på Canada. Thule anvendes allerede af forsvaret til visse formål, fx forsyning af Station Nord og flyvninger nord for Grønland. Men i fremtiden kan der meget vel tænkes en mere substantiel anvendelse af basen, der generelt er præget af et stadig lavere aktivitetsniveau.

Den danske interesse kunne være anvendelse af Thule som basishavn for patruljering i nordgrønlandske farvande ud fra en forventning om øget skibstrafik i disse. Desuden kan Thule-basen være base for luftovervågning omkring Nordgrønland, $\mathrm{fx}$ ved indsættelse af danske kampfly i opgaven.

Traktatmæssigt er der god dæk- 
ning herfor i forsvarsaftalen af 1951, hvis Art. II c stipulerer, at den danske regering forbeholder sig ret til i samarbejde med USA at benytte de amerikansk-drevne forsvarsområder i forsvaret af Grønland. Artiklen har aldrig været brugt, men må anses for at være fortsat gyldig .

Endelig er der tanken om en arktisk indsatsstyrke med henblik på generelt større dansk kompetence på området og til indsættelse 'i Grønland eller i internationale opgaver $i$ arktisk miljø'. Formuleringen minder om terminologien omkring forsvarets oversøiske engagementer og er den hidtil stærkeste indikation af, at Arktis i hvert fald til en vis grad betragtes med de samme briller som andre danske engagementer i verden.

Problemet er imidlertid, at det er ganske uklart, hvad der ligger i formuleringen. For øjeblikket synes der ikke at være nogen, der har en klar forståelse af, hvad styrken skal kunne, hvor den skal indsættes eller hvilke opgaver den skal løse. Dette må være en væsentlig opgave for den kommende Arktis-analyse.

\section{Samarbejde eller konflikt}

Billedet af fremtidens Arktis er stadig uklart, hvad angår opgaverne for dansk udenrigs- og sikkerhedspolitik. Disse opgaver kan praktisk kan inddeles i fire typer (jf. figur 1): regimeopgaver, myndighedsopgaver, suverænitetsopgaver og forsvarsop- gaver, hvis indbyrdes prioritering vil afhænge af, hvor på kontinuet samarbejde-konflikt man til enhver tid befinder sig.

Hvis samarbejde skulle blive det dominerende træk i arktisk politik, vil en koncentration om regimeopgaver være naturlig. I denne situation vil hidtil nationale myndighedsopgaver i stigende grad blive varetaget inden for de relevante regimer, idet kyststaten fortsat vil være leverandør af de pågældende regimegode, hvad enten det drejer søopmåling, is- og vejrtjeneste m.v.

I et sådant samarbejdssystem vil suverænitetsopgaver blive mindre presserende, om end de fortsat vil blive opretholdt. Derimod vil der ikke være et øget behov for en egentlig arktisk forsvarskapacitet.

Hvis omvendt konflikter og gensidig mistillid bliver dominerende i arktisk politik, bliver det nødvendigt at tænke på en styrkelse af forsvarsevnen samt suverænitetshævdelsen og den nationale myndighedsudøvelse. Derimod vil regimeopgaverne blive begrænsede, om end ikke nødvendigvis fraværende.

Afklaringen af, hvor på samarbejds-konfliktkontinuet den arktiske politik vil placere sig, vil først efterhånden aftegne sig; det sandsynlige vil dog være en placering et sted midt imellem. En tidlig lakmusprøve vil blive, hvorledes de arktiske kyststater vil håndtere overlappende krav på den ydre kontinentalsokkel, og hvorledes de vil forholde sig til 
UNCLOS-komiteens afgørelse. De russiske krav skal (gen)fremsættes i år, mens Danmark og Canada har frist til 2014.

En sådan både- og situation vil stille det enkelte land over for betydelige krav til at finde den rette balance mellem samarbejdsinitiativer og konfliktadfærd. Hvordan vil være et vigtigt spørgsmål for den kommende Arktis-undersøgelse.

Mens samarbejde-konflikt er uafgjort, synes det rimeligt klart, at de kommende år vil se en vækst i skibstrafikken i Arktis, inklusive grønlandske farvande, hvorfor det ikke er for tidligt at overveje og forberede en styrkelse af kapaciteten til løsning af myndigheds- og suveræni- tetsopgaverne. Det er det, der sker i et vist omfang under det nye forsvarsforlig, men det synes at være et sikkert gæt, at næste forsvarsforlig vil gå videre i den retning.

Til den tid vil udviklingen og den gennemførte analyse af forsvarets opgaver i Grønland formentlig have skabt et sikrere billede af den indbyrdes prioritering af regime- og forsvarsopgave. Næste forsvarsforlig vil måske også i stærkere grad end det aktuelle blive stillet over for en egentlig prioritering af arktiske og internationale opgaver for det danske forsvar.

Nikolaj Petersen er professor emeritus (international politik) på Aarhus Universi- 